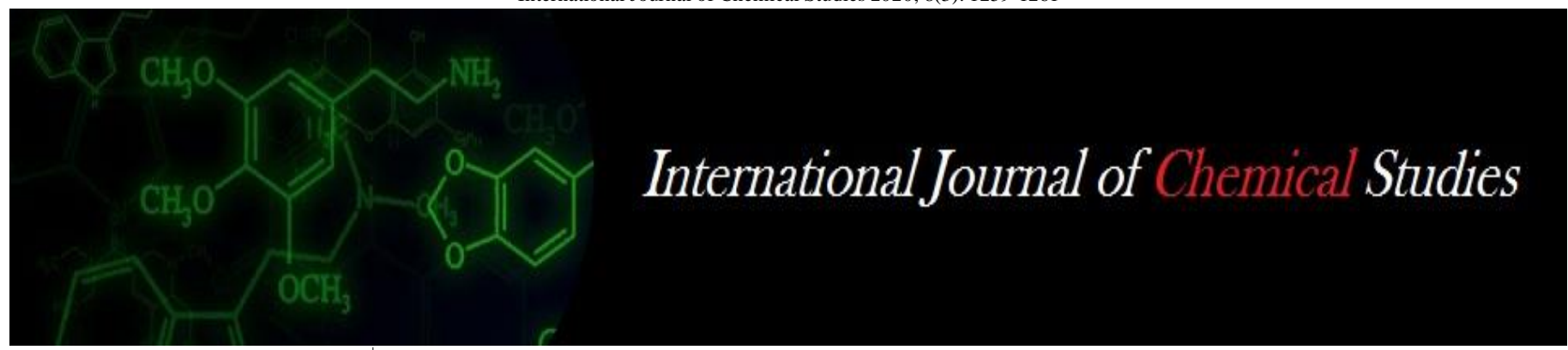

P-ISSN: 2349-8528

E-ISSN: 2321-4902

www.chemijournal.com

IJCS 2020; 8(3): 1259-1261

(C) 2020 IJCS

Received: 16-03-2020

Accepted: 18-04-2020

Abhimanyu Patel

Department of Horticulture,

Naini Agricultural Institute,

Sam Higginbottom University of

Agriculture, Technology and

Sciences, Allahabad, Uttar

Pradesh, India

\section{Urfi Fatmi}

Department of Horticulture,

Naini Agricultural Institute,

Sam Higginbottom University of

Agriculture, Technology and

Sciences, Allahabad, Uttar

Pradesh, India

\section{Ravi kumar}

Department of Horticulture, Naini Agricultural Institute,

Sam Higginbottom University of

Agriculture, Technology and

Sciences, Allahabad, Uttar

Pradesh, India
Corresponding Author:

Abhimanyu Patel

Department of Horticulture,

Naini Agricultural Institute,

Sam Higginbottom University of

Agriculture, Technology and

Sciences, Allahabad, Uttar

Pradesh, India

\section{Effects of potting media on survival and growth of different species of Dracaena (D. marginata, $D$. reflexa, and D. mahatma) under shade net conditions}

\author{
Abhimanyu Patel, Urfi Fatmi and Ravi kumar
}

DOI: $\underline{\text { https://doi.org/10.22271/chemi.2020.v8.i3q.9373 }}$

\begin{abstract}
The research study was carried out to investigate "Effects of potting media on survival and growth of different species of Dracaena (D. marginata, D. reflexa, and D. mahatma) under shade net conditions Allahabad" at the Department of Horticulture, Naini Agricultural Institute, Sam Higginbottom University of Agriculture, Technology and Sciences using Factorial randomized block design of experiment. Three species were evaluated with five different growing media in shade net condition. Coco peat (CP), vermicompost (VC), farm yard manure (FYM), rice husk, sand and soils in different combination were used as growing media. Maximum plant height $(58.17 \mathrm{~cm})$, plant spread $(46.67 \mathrm{~cm})$ and rhizosphere $(21.50 \mathrm{~cm})$ was recorded in $D$. marginata with media containing coco peat + sand + vermicompost in $(1: 1: 1)$ combination, maximum number of leaves $(35.16)$ and root length $(27.00 \mathrm{~cm})$ was recorded in $D$. reflexa with media containing coco peat + sand + vermicompost in $(1: 1: 1)$ combination and chlorophyll content and leaf area $\left(338.00 \mathrm{~cm}^{2}\right)$ were recorded $D$. mahatma with the media containing coco peat + sand + vermicompost in $(1: 1: 1)$ combination.
\end{abstract}

Keywords: Dracaena, coco peat, vermicompost, farm yard manure, rice husk, sand and soils

\section{Introduction}

The genus Dracaena belongs to the botanical family Dracaenaceae. Its centre of origin is located in tropical and subtropical regions of Africa, Asia and Australia. Among a large number of foliage plants available for interior decoration, Dracaena is an important and popular herbaceous evergreen ornamental foliage plant with attractive foliar variegation and tolerance to low light. These species are favoured as interior ornamental plants because of their diverse shapes, colours and forms available in the market and because of their ability to survive under low-light conditions with minimum care (Chen and Henny, 2008) ${ }^{[2]}$. Indoor plants also fulfill psychological needs of people by providing green color and comfort and enhance the indoor environment to make it more aesthetically pleasing (Bringslimark et al., 2007) ${ }^{[1]}$. This large group of plants includes many species that can grow up to 6 feet tall with long, strap-like leaves, often with red and yellow variegation. As the plant grows, the lower leaves drop off and the trunk scar over, creating an interesting pattern of marking. Plants can effectively improve the indoor air quality by reducing volatile organic compounds, such as formaldehyde, benzene, toluene, ethylene, and xylene (Thomsen et al., 2011) ${ }^{[5]}$. Soilless media have proven popular with the majority of producers because of consistency, excellent aeration, reproducibility, and low bulk density that reduce shipping and handling costs of the medium itself and of the finished plants. In potted plants nowadays soilless media are used as growing media because of its tremendous benefits i.e., good water holding capacity, porosity, aeration and free from water logging conditions and less chances of weed growth, pest and disease infestation. In present study, coco peat, vermicompost, farmyard manure, rice husk, sand and soil were used in different proportions. The choice of urban landscaping is very popular among people by decorating houses with potted indoor plants for which ideal growing media is also required. So, the present study aims to provide this data for exploring the growth of best species of Dracaena using different growing media under shade net conditions for better quality production of ornamental foliage. 


\section{Material and methods}

A research was conducted on "Effects of Potting media on survival and growth of different species of Dracaena under shade-net conditions" will be carried out at Horticultural Experimental Field in the Department of Horticulture, Naini Agriculture Institute, Sam Higginbottom University of Agriculture Technology and Sciences (SHUATS), Allahabad during season of 2017-18, which is situated in the agro climatic zone of Uttar Pradesh state. The experiment was laid out in Factorial Randomized Block Design with three replication comprised of 3 Dracaena specie i.e., D. marginata $\left(\mathrm{S}_{1}\right)$, D. reflexa $\left(\mathrm{S}_{2}\right)$ and D. mahatma $\left(\mathrm{S}_{3}\right)$ and 5 potting medium combinations i.e., $\mathrm{M}_{1}$ (soil with ratio 1 ), $\mathrm{M}_{2}$ (coco peat+ sand+ FYM with ratio 1:1:1), $\mathrm{M}_{3}$ (coco peat+ rice husk+ FYM with ratio 1:1:1), $\mathrm{M}_{4}$ (coco peat+ sand+ vermicompost with ratio $1: 1: 1$ ), and $\mathrm{M}_{5}$ (coco peat+ rice husk+ vermicompost with ratio $1: 1: 1)$ at $5 \%$ significance were studied during the field investigation.

The different treatment combinations are as follows; $\mathrm{T}_{1}$ $\left(\mathrm{S}_{1} \mathrm{M}_{1}\right), \mathrm{T}_{2}\left(\mathrm{~S}_{1} \mathrm{M}_{2}\right), \mathrm{T}_{3}\left(\mathrm{~S}_{1} \mathrm{M}_{3}\right), \mathrm{T}_{4}\left(\mathrm{~S}_{1} \mathrm{M}_{4}\right), \mathrm{T}_{5}\left(\mathrm{~S}_{1} \mathrm{M}_{5}\right), \mathrm{T}_{6}$ $\left(\mathrm{S}_{2} \mathrm{M}_{1}\right), \mathrm{T}_{7}\left(\mathrm{~S}_{2} \mathrm{M}_{2}\right), \mathrm{T}_{8}\left(\mathrm{~S}_{2} \mathrm{M}_{3}\right), \mathrm{T}_{9}\left(\mathrm{~S}_{2} \mathrm{M}_{4}\right), \mathrm{T}_{10}\left(\mathrm{~S}_{2} \mathrm{M}_{5}\right), \mathrm{T}_{11}$ $\left(\mathrm{S}_{3} \mathrm{M}_{1}\right), \mathrm{T}_{12}\left(\mathrm{~S}_{3} \mathrm{M}_{2}\right), \mathrm{T}_{13}\left(\mathrm{~S}_{3} \mathrm{M}_{3}\right), \mathrm{T}_{14}\left(\mathrm{~S}_{3} \mathrm{M}_{4}\right)$ and $\mathrm{T}_{15}\left(\mathrm{~S}_{3} \mathrm{M}_{5}\right)$. The growth parameters including plant height $(\mathrm{cm})$, number of leaves, plant spread $(\mathrm{cm})$, leaf area $\left(\mathrm{cm}^{2}\right)$, root length $(\mathrm{cm})$, rhizosphere $(\mathrm{cm})$, and chlorophyll content $(\mathrm{mg})$. Were recorded at 30,60, 90, 120, 150 DAP and survival percentage at 30 days after planting.

\section{Results and discussion}

Plant height was found to be significant among all treatments. Maximum $(58.17 \mathrm{~cm})$ was observed in $\mathrm{S}_{1} \mathrm{M}_{4}$ (D.marginata+ cocopeat+ sand+ vermicompost) followed by $(48.00 \mathrm{~cm})$ $\mathrm{S}_{2} \mathrm{M}_{4}$ (D. reflexa+ cocopeat+ sand+ vermicompost) and minimum in $(37.25 \mathrm{~cm})$ was observed in $\mathrm{S}_{3} \mathrm{M}_{1}($ D. mahatma+ soil). Maximum number of leaves (35.16) was observed in $\mathrm{S}_{2} \mathrm{M}_{3}$ (D. reflexa+ cocopeat+ rice husk + FYM) followed by (22.83) $\quad \mathrm{S}_{1} \mathrm{M}_{4} \quad($ D. marginata+ cocopeat+ sand+ vermicompost) and minimum in (4.00) was observed in $S_{3} M_{1}$ (D. mahatma + soil). Maximum plant spread $(46.67 \mathrm{~cm})$ was observed in $\mathrm{S}_{1} \mathrm{M}_{4}$ (D.marginata+ cocopeat+ sand+ vermicompost) followed by $(31.58 \mathrm{~cm}) \mathrm{S}_{3} \mathrm{M}_{2}$ (D. mahatma+ cocopeat+ sand+ FYM) and minimum in $(23.00 \mathrm{~cm})$ was observed in $\mathrm{S}_{2} \mathrm{M}_{1}$ (D. reflexa+ soil) shows in table:1. Maximum chlorophyll A (2.76 mg) was observed in $\mathrm{S}_{3} \mathrm{M}_{4}$ (D.mahatma+ cocopeat+ sand+ vermicompost) followed by $(1.85 \mathrm{mg}) \quad \mathrm{S}_{1} \mathrm{M}_{5}$ (D. marginata+ cocopeat+ rice husk+ vermicompost) and minimum in $(0.92 \mathrm{mg})$ was observed in $\mathrm{S}_{2} \mathrm{M}_{1}$ (D. reflexa+ soil). Maximum chlorophyll B $(1.44 \mathrm{mg})$ was observed in $\mathrm{S}_{3} \mathrm{M}_{4}$ (D.mahatma+ cocopeat+ sand+ vermicompost) followed by $(0.90 \mathrm{mg}) \mathrm{S}_{1} \mathrm{M}_{2}$ (D. marginata+ cocopeat+ sand+ FYM) and minimum in $(0.45 \mathrm{mg})$ was observed in $\mathrm{S}_{2} \mathrm{M}_{1}$ (D. reflexa+ soil). Maximum total chlorophyll $\left(4.08 \mathrm{mg}\right.$ ) was observed in $\mathrm{S}_{3} \mathrm{M}_{4}$ (D.mahatma+ cocopeat+ sand+ vermicompost) followed by $(2.75 \mathrm{mg}) \mathrm{S}_{1} \mathrm{M}_{5}$ (D. marginata+ cocopeat+ rice husk+ vermicompost) and minimum in $(1.45 \mathrm{mg})$ was observed in $\mathrm{S}_{2} \mathrm{M}_{1}(D$. reflexa+ soil) shows in table:2. Maximum leaf area $\left(338.00 \mathrm{~cm}^{2}\right)$ was observed in $\mathrm{S}_{3} \mathrm{M}_{4}$ (D.mahatma+ cocopeat+ sand+ vermicompost $)$ followed by $\left(200.00 \quad \mathrm{~cm}^{2}\right) \quad \mathrm{S}_{1} \mathrm{M}_{3} \quad(D$. marginata+ cocopeat+ rice husk+ FYM) and minimum in $\left(178.00 \mathrm{~cm}^{2}\right)$ was observed in $\mathrm{S}_{2} \mathrm{M}_{1}$ (D. reflexa+ soil). Maximum root length $(27.00 \mathrm{~cm})$ was observed in $\mathrm{S}_{2} \mathrm{M}_{4}(D$. reflexa+ cocopeat+ sand+ vermicompost) followed by $(22.00$ cm) $\mathrm{S}_{3} \mathrm{M}_{3}$ (D. mahatma+ cocopeat+ rice husk+ FYM) and minimum in $(15.00 \mathrm{~cm})$ was observed in $\mathrm{S}_{1} \mathrm{M}_{2}$ (D. marginata+ cocopeat+ sand+ FYM). Maximum rhizosphere $(21.50 \mathrm{~cm})$ was observed in $\mathrm{S}_{1} \mathrm{M}_{4}(D$. marginata+ cocopeat+ sand+ vermicompost) followed by $(20.50 \mathrm{~cm}) \mathrm{S}_{2} \mathrm{M}_{4}(D$. reflexa+ cocopeat+ sand+ vermicompost) and minimum in $(14.00 \mathrm{~cm})$ was observed in $\mathrm{S}_{3} \mathrm{M}_{1}(D$. mahatma+ soil) shows in table:3.Maximum survival percentage there was no significant effect of different media on survival percentage of different species of Dracaena.

The difference in plant height number of leaves, plant spread $(\mathrm{cm})$, leaf area $\left(\mathrm{cm}^{2}\right)$, root length $(\mathrm{cm})$, rhizosphere $(\mathrm{cm})$, and chlorophyll content $(\mathrm{mg})$ and survival percentage are due to different potting media and vigour of the species under study. Potting media which effect the physiological characters.viz, bulk density, porosity, water holding capacity and free from water logging conditions and less chances of weed growth, pest and disease infestation etc.

Table 1: Effects of potting media on different species of Dracaena

\begin{tabular}{|c|c|c|c|c|c|c|c|c|c|}
\hline \multirow{2}{*}{ Species (A) } & \multirow{2}{*}{\multicolumn{3}{|c|}{$\begin{array}{c}\text { Plant height }(\mathrm{cm}) \\
\text { Media }(\mathrm{B})\end{array}$}} & \multirow{2}{*}{\multicolumn{3}{|c|}{$\begin{array}{c}\text { Number of leaves } \\
\text { Media (B) }\end{array}$}} & \multirow{2}{*}{\multicolumn{2}{|c|}{$\begin{array}{c}\text { Plant spread }(\mathrm{cm}) \\
\text { Media }(\mathrm{B})\end{array}$}} & \multirow[b]{3}{*}{ S3 } \\
\hline & & & & & & & & & \\
\hline & $\mathrm{S} 1$ & $\mathrm{~S} 2$ & S3 & $\mathrm{S} 1$ & $\mathrm{~S} 2$ & S3 & S1 & $\mathrm{S} 2$ & \\
\hline M1 & 53.33 & 44.33 & 37.25 & 44.17 & 31.50 & 23.00 & 44.17 & 31.50 & 23.00 \\
\hline M2 & 49.67 & 46.67 & 44.00 & 44.42 & 31.58 & 29.25 & 44.42 & 31.58 & 29.25 \\
\hline M3 & 55.33 & 45.50 & 45.58 & 44.75 & 29.17 & 31.50 & 44.75 & 29.17 & 31.50 \\
\hline M4 & 58.17 & 48.00 & 44.00 & 46.67 & 31.00 & 32.41 & 46.67 & 31.00 & 32.41 \\
\hline M5 & 54.83 & 46.83 & 42.33 & 46.92 & 31.83 & 23.00 & 46.92 & 31.83 & 23.00 \\
\hline Comparision & F-test & $\operatorname{S.Ed}( \pm)$ & C.D. at 5\% & F-test & S.Ed( $( \pm)$ & C.D. at $5 \%$ & F-test & S.Ed $( \pm)$ & C.D. at $5 \%$ \\
\hline Due to species & $\mathrm{S}$ & 0.600 & 2.073 & $\mathrm{~S}$ & 0.435 & 3.168 & $\mathrm{~S}$ & 0.435 & 3.168 \\
\hline Due to media & $\mathrm{S}$ & 0.775 & 2.673 & $\mathrm{~S}$ & 0.561 & 4.099 & $\mathrm{~S}$ & 0.561 & 4.099 \\
\hline Due to both $(\mathrm{S} \times \mathrm{M})$ & $\mathrm{S}$ & 1.342 & 4.647 & $\mathrm{~S}$ & 0.972 & 7.086 & $\mathrm{~S}$ & 0.972 & 7.086 \\
\hline
\end{tabular}

Table 2: Effects of potting media on different species of Dracaena

\begin{tabular}{|c|c|c|c|c|c|c|c|c|c|}
\hline \multirow{2}{*}{ Species (A) } & \multirow{2}{*}{\multicolumn{3}{|c|}{$\begin{array}{c}\text { Chlorophyll a (mg) } \\
\text { Media (B) }\end{array}$}} & \multirow{2}{*}{\multicolumn{3}{|c|}{$\begin{array}{c}\text { Chlorophyll b (mg) } \\
\text { Media (B) }\end{array}$}} & \multirow{2}{*}{\multicolumn{2}{|c|}{$\frac{\text { Total chlorophyll (mg) }}{\text { Media }(B)}$}} & \multirow[b]{3}{*}{ S3 } \\
\hline & & & & & & & & & \\
\hline & $\mathrm{S} 1$ & $\mathrm{~S} 2$ & S3 & $\mathrm{S} 1$ & $\mathrm{~S} 2$ & S3 & S1 & S2 & \\
\hline M1 & 1.73 & 0.92 & 1.84 & 0.67 & 0.45 & 0.91 & 2.55 & 1.45 & 2.96 \\
\hline M2 & 1.51 & 1.08 & 2.47 & 0.90 & 0.48 & 1.01 & 2.38 & 1.51 & 3.18 \\
\hline M3 & 1.71 & 1.05 & 2.28 & 0.68 & 0.47 & 1.32 & 2.16 & 1.59 & 3.91 \\
\hline M4 & 1.60 & 0.93 & 2.76 & 0.65 & 0.52 & 1.44 & 2.29 & 1.39 & 4.08 \\
\hline M5 & 1.85 & 0.99 & 1.76 & 0.82 & 0.48 & 1.11 & 2.75 & 1.47 & 2.77 \\
\hline
\end{tabular}




\begin{tabular}{|c|c|c|c|c|c|c|c|c|c|}
\hline Comparision & F-test & S.Ed( \pm ) & C.D. at 5\% & F-test & S.Ed( \pm ) & C.D. at 5\% & F-test & S.Ed( \pm ) & C.D. at 5\% \\
\hline Due to species & S & 0.030 & 1.687 & S & 0.032 & 1.687 & S & 0.064 & 8.254 \\
\hline Due to media & S & 0.038 & 2.179 & S & 0.041 & 2.179 & S & 0.082 & 1.065 \\
\hline Due to both $(\mathrm{S} \times \mathrm{M})$ & $\mathrm{S}$ & 0.067 & 3.761 & $\mathrm{~S}$ & 0.071 & 3.761 & $\mathrm{~S}$ & 0.142 & 1.845 \\
\hline
\end{tabular}

Table 3: Effects of potting media on different species of Dracaena

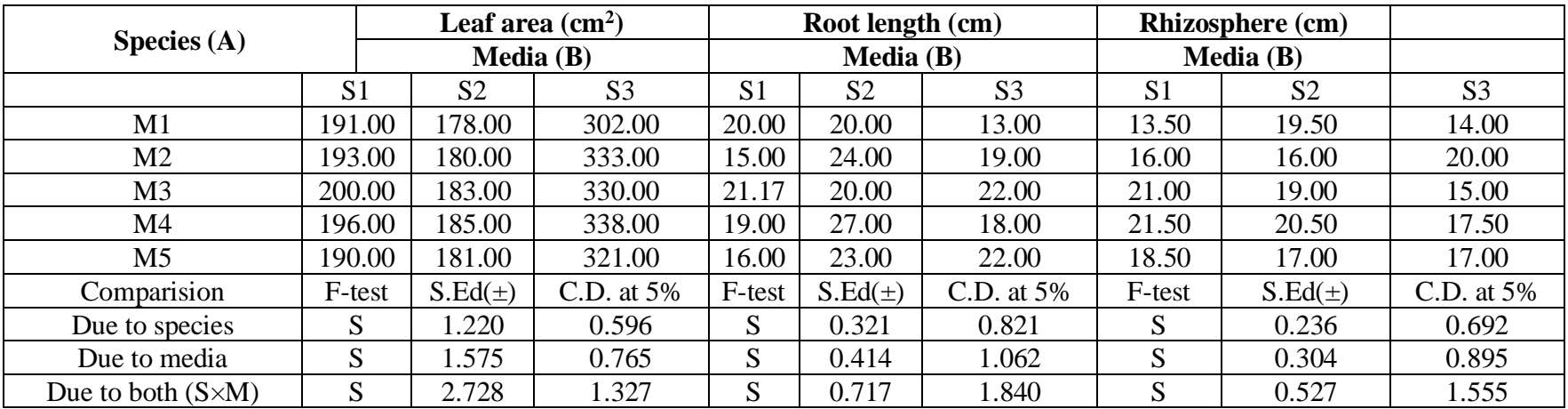

\section{Conclusion}

On the basis of the findings obtained it is concluded that Dracaena marginata was the most suitable species under $25 \%$ green shade net conditions of Allahabad agro-climatic region with cocopeat+ sand+ vermicompost $(1: 1: 1)$ as the growing medium

\section{References}

1. Bringslimark T, Hartig T, Patil GG. Psychological benefits of indoor plants in workplaces: Putting experimental results into context. Hort Science. 2007; 2:581-587.

2. Chen J, Henny RJ. Recent advances in plant biotechnology and its applications, Ornamental foliage plants: Improvement through biotechnology, edn Kumar A., Sopory S.K. (I.K. International Publishing House, New Delhi, India), 2008, 140-156.

3. Ikram S, Habib U, Khalid N. Effect of different potting media combinations on growth and vase life of tuberose (Polianthes tuberosa Linn.) Pak. J. Agri. Sci. 2012; 49(2):121-125.

4. Kim HH, Lee JY, Yang JY, Kim KJ, Lee YJ, Shin DC, et al. Evaluation of indoor air quality and health related parameters in office buildings with or without indoor plants. J. Jpn. Soc. Hort. Sci. 2011; 80:96-102.

5. Thomsen JD, Sonderstrup-Andersen HKH. Muller R. People-plant relationships in an office workplace: Perceived benefits for the workplace and employees. Hort Science. 2011; 46:744-752. 